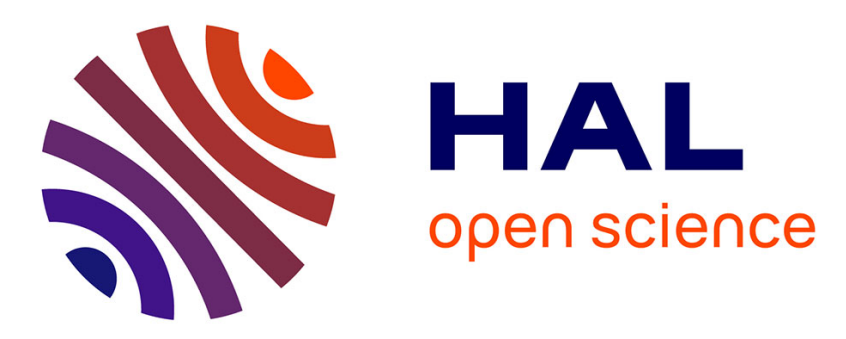

\title{
Iron/Caffeine as a Catalytic System for Microwave-Promoted Benzamide Formation
}

Xavier Bantreil, Pauline Navals, Jean Martinez, Frédéric Lamaty

\section{To cite this version:}

Xavier Bantreil, Pauline Navals, Jean Martinez, Frédéric Lamaty. Iron/Caffeine as a Catalytic System for Microwave-Promoted Benzamide Formation. European Journal of Organic Chemistry, 2015, 2015 (2), pp.417-422. 10.1002/ejoc.201403173 . hal-01114591

\section{HAL Id: hal-01114591 https://hal.science/hal-01114591}

Submitted on 3 Mar 2021

HAL is a multi-disciplinary open access archive for the deposit and dissemination of scientific research documents, whether they are published or not. The documents may come from teaching and research institutions in France or abroad, or from public or private research centers.
L'archive ouverte pluridisciplinaire HAL, est destinée au dépôt et à la diffusion de documents scientifiques de niveau recherche, publiés ou non, émanant des établissements d'enseignement et de recherche français ou étrangers, des laboratoires publics ou privés. 


\title{
Iron/Caffeine as a Catalytic System for Microwave-Promoted Benzamide Formation
}

\author{
Xavier Bantreil, ${ }^{*[a]}$ Pauline Navals, ${ }^{[a]}$ Jean Martinez, ${ }^{[a]}$ and Frédéric Lamaty*[a]
}

Dedicated to Professor Max Malacria on the occasion of his 65th birthday

Keywords: Homogeneous catalysis / Oxidation / Microwave chemistry / Amides / Iron

The amide bond is an essential unit in many drugs and polymers. The catalyzed oxidation of alcohols and amines is an effective method to form amides with limited undesired waste. Herein, we demonstrate the beneficial effect of microwave activation for this reaction. The benzamides were directly formed from alcohols and amine hydrochloride salts in short reaction times with yields up to $84 \%$ and TOFs (turn- over frequencies) up to $33.6 \mathrm{~h}^{-1}$. Among the examined transition metals, only nontoxic and inexpensive $\mathrm{FeCl}_{2} \cdot 4 \mathrm{H}_{2} \mathrm{O}$ together with caffeine as a stabilizing ligand provided a uniquely efficient catalytic system for the transformation. Natural sources of caffeine were also evaluated under the amidation conditions.

\section{Introduction}

The amide functional group is present in numerous highly valuable compounds. ${ }^{[1]}$ Because of its distinct planar structure and polarity, the amide group participates in interactions (e.g., hydrogen bonding or electrostatic interactions) that are closely related to the activity of a compound. Many natural products, peptides, and proteins, as well as non-natural drugs and polymers contain an amide group. Several structures of pharmaceutical compounds that have an amide moiety are depicted in Figure 1. In most cases, the amide functionality in those molecules was introduced by a carboxylic acid that was activated by using a stoichiometric amount of an acylating or coupling agent. Although a wide variety of coupling agents have been developed, ${ }^{[2]}$ most methods generate an excess amount of undesired waste.

To develop new methods to efficiently form amide bonds and reduce the impact on the environment, chemists have turned their attention to catalysis. ${ }^{[3]}$ Among the most recent techniques, boronic acid catalyzed couplings ${ }^{[4]}$ and metalcatalyzed reactions ${ }^{[5]}$ have attracted much attention. In particular, since the pioneering works on ruthenium ${ }^{[6]}$ and rhodium chemistry, ${ }^{[7]}$ the oxidative coupling of alcohols and

[a] Institut des Biomolécules Max Mousseron (IBMM), UMR 5247 CNRS-Universités Montpellier 1 et 2-ENSCM, Bâtiment Chimie (17), Université Montpellier 2,

Place Eugène Bataillon, 34095 Montpellier cedex 5, France

E-mail: frederic.lamaty@univ-montp2.fr xavier.bantreil@univ-montp2.fr

www.greenchem.univ-montp2.fr<smiles>CCNCCNC(=O)c1cc(Cl)c(N)cc1OC</smiles>

Figure 1. Structure of pharmaceutical compounds that feature an amide bond.

amines into the corresponding amides has been widely studied. Much effort has been devoted to finding conditions that employ less expensive and less toxic transition metals than $\mathrm{Ru}$ and $\mathrm{Rh}$. In this context, we recently demonstrated that amides could be directly obtained from benzylic alcohols and amines in the presence of tert-butyl hydroperoxide (TBHP) as the oxidant and by using copper as an inexpensive and nontoxic catalyst. ${ }^{\left[{ }^{[3}\right.}$ Since then, copper nanoparticles, ${ }^{[9]}$ zinc, $^{[10]}$ and iron ${ }^{[11]}$ have been proven to catalyze this domino reaction efficiently. One major improvement of these procedures would be to combine the efficiency of the catalytic system with an activation method such as microwaves. Indeed, although microwave activation has been widely studied and efficiently used in organic synthesis as well as organometallic chemistry, ${ }^{[12]}$ its beneficial 
effects in the oxidation of alcohols into amides have never been witnessed. ${ }^{[13]}$ Herein, among the transition metals described above, we demonstrated that only iron in combination with a suitable caffeine ligand was able to promote the efficient formation of benzamide upon microwave activation.

\section{Results and Discussion}

We began our study of microwave activation by directly adapting the conditions from our last report about benzamide formation. ${ }^{[11 \mathrm{c}]}$ However, under those reaction conditions, the use of $\mathrm{CaCO}_{3}$ as the base provoked a fast release of $\mathrm{CO}_{2}$, which resulted in a sudden and dangerous rise of pressure in the sealed microwave reactor. Such behavior prompted us to turn our attention toward others bases that would be able to mimic the reactivity of calcium carbonate and slowly liberate the free amine in the reaction mixture. ${ }^{[14]}$ To modulate the equilibrium for the deprotonation of the $(\alpha)$-methylbenzylamine hydrochloride salt $\left(\mathrm{p} K_{\mathrm{a}}=\right.$ $9.83^{[15]}$ ), a screening of organic bases with different $\mathrm{p} K_{\mathrm{a}}$ values was performed (see Figure 2). The use of pyridine ( $\mathrm{p} K_{\mathrm{a}}$ $=5.14)^{[16]}$ afforded the formation of amide $3 \mathrm{aa}$ in $55 \%$ isolated yield. By lowering the $\mathrm{p} K_{\mathrm{a}}$ value of the base to between 2.84 (3-chloropyridine) and 0.61 (caffeine), thereby reducing the formation of the free amine in the reaction mixture, we observed an increase in the yield to $71 \%$. However, urea and 2-fluoropyridine, with very low $\mathrm{p} K_{\mathrm{a}}$ values, proved inefficient. Among the three optimal bases, caffeine, which is less toxic and less expensive, was selected for further studies.

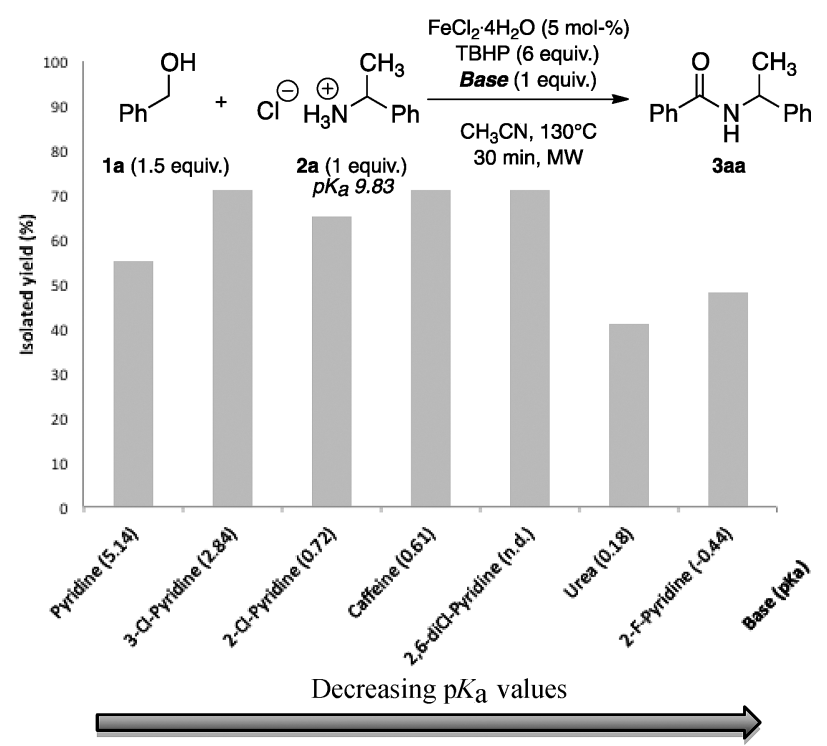

Figure 2. Variation of the base for microwave-assisted formation of 3aa $(\mathrm{MW}=$ microwave $)$.

Copper, ${ }^{[8]}$ manganese, ${ }^{[17]}$ zinc, ${ }^{[10]}$ and iron,,${ }^{[11 \mathrm{a}, 11 \mathrm{c}]}$ which were reported to efficiently participate in the formation of benzamides under traditional activation conditions in the presence of TBHP, were subjected to the microwave-acti- vated reaction (see Table 1, Entries 1-4). Among them, only iron was able to give a satisfactory $71 \%$ isolated yield. Several iron(II) and iron(III) salts were then evaluated, which confirmed that $\mathrm{FeCl}_{2} \cdot 4 \mathrm{H}_{2} \mathrm{O}$ was the best candidate (see Table 1, Entries 4-7). Lowering or increasing the catalyst loading did not improve the $71 \%$ yield (see Table 1, Entries 8 and 9). Gratifyingly, 3aa could be isolated in $84 \%$ yield by using 2 equiv. of 1a (see Table 1, Entry 10). As explained earlier, caffeine was introduced as a very weak base to allow for the slow deprotonation of 2a. However, when a catalytic amount of caffeine was used $(10 \mathrm{~mol}-\%$, see Table 1, Entry 11), 3aa was isolated in $81 \%$ yield, which demonstrates that caffeine might not act as a base but as a possible stabilizing ligand of iron. Such an interaction is well accepted under physiological conditions, as caffeine from drinking tea or coffee is strongly suspected to prevent iron absorption in the human body. ${ }^{[18]}$ The beneficial effect of caffeine was confirmed when the amount was reduced to 5 and $0 \mathrm{~mol}-\%$, which resulted in a decrease of yield (see Table 1, Entries 12 and 13). Replacing caffeine with the structurally simplified analogue $N$-methylimidazole (10 mol- $\%)$ resulted in a decreased yield of $45 \%$. This confirmed the necessity of the complete bicyclic structure of caffeine for an optimum yield. Such behavior tends to support a simplified mechanism in which the hydrochloride salt of amine A slowly releases free amine $\mathbf{A}^{\prime}$ and hydrochloric acid into the reaction media. In the meantime, alcohol $\mathbf{B}$ is oxidized into the corresponding aldehyde $\mathbf{C}$, which consumes the available free amine in the mixture to form hemiaminal D. Upon oxidation, D converts into benzamide $\mathbf{E}$ (see Scheme 1). Finally, the best reagents and amounts (see Table 1, Entry 11) were employed, but the reaction was carried out by using traditional heating at $80^{\circ} \mathrm{C}$ for $4 \mathrm{~h}$ instead (see Table 1, Entry 14). In this case, amide 3aa was isolated in only $18 \%$ yield, which attests to the remarkable synergistic effect of microwave activation with the iron/caffeine catalytic system.

Table 1. Variation of the conditions for microwave-assisted formation of 3aa. [a] $^{[a}$

\begin{tabular}{llcc}
\hline Entry & Catalyst [mol- $\%]$ & Caffeine [mol- $\%$ ] & Yield [\%] $^{[\mathrm{b}]}$ \\
\hline 1 & $\mathrm{CuSO}_{4}(5 \%)$ & 100 & 34 \\
2 & $\mathrm{MnO}_{2}(5 \%)$ & 100 & 35 \\
3 & $\mathrm{ZnI}_{2}(5 \%)$ & 100 & n.d..$^{[\mathrm{c}]}$ \\
4 & $\mathrm{FeCl}_{2} \cdot 4 \mathrm{H}_{2} \mathrm{O}(5 \%)$ & 100 & 71 \\
5 & $\mathrm{FeCl}_{3} \cdot 6 \mathrm{H}_{2} \mathrm{O}(5 \%)$ & 100 & 43 \\
6 & $\mathrm{FeSO}_{4} \cdot 7 \mathrm{H}_{2} \mathrm{O}(5 \%)$ & 100 & 56 \\
7 & $\mathrm{Fe}\left(\mathrm{NO}_{3}\right) \cdot 9 \mathrm{H}_{2} \mathrm{O}(5 \%)$ & 100 & 59 \\
8 & $\mathrm{FeCl}_{2} \cdot 4 \mathrm{H}_{2} \mathrm{O}(1 \%)$ & 100 & 48 \\
9 & $\mathrm{FeCl}_{2} \cdot 4 \mathrm{H}_{2} \mathrm{O}(10 \%)$ & 100 & 70 \\
10 & $\mathrm{FeCl}_{2} \cdot 4 \mathrm{H}_{2} \mathrm{O}(5 \%)$ & 100 & $84^{[\mathrm{d}]}$ \\
11 & $\mathrm{FeCl}_{2} \cdot 4 \mathrm{H}_{2} \mathrm{O}(5 \%)$ & 10 & $81^{[\mathrm{d}]}$ \\
12 & $\mathrm{FeCl}_{2} \cdot 4 \mathrm{H}_{2} \mathrm{O}(5 \%)$ & 5 & $71^{[\mathrm{d}]}$ \\
13 & $\mathrm{FeCl}_{2} \cdot 4 \mathrm{H}_{2} \mathrm{O}(5 \%)$ & 0 & $66^{[\mathrm{d}]}$ \\
14 & $\mathrm{FeCl}_{2} \cdot 4 \mathrm{H}_{2} \mathrm{O}(5 \%)$ & 10 & $18^{[\mathrm{d}, \mathrm{e}]}$ \\
\hline
\end{tabular}

[a] Reagents and conditions: $\mathbf{2 a}(0.5 \mathrm{mmol}), \mathbf{1 a}(0.75 \mathrm{mmol})$, caffeine, TBHP $\left(70 \%\right.$ in $\left.\mathrm{H}_{2} \mathrm{O}, 3.0 \mathrm{mmol}\right)$, catalyst, $\mathrm{CH}_{3} \mathrm{CN}(1 \mathrm{~mL})$, $130{ }^{\circ} \mathrm{C}, \mathrm{MW}, 30 \mathrm{~min}$. [b] Isolated yield. [c] Not determined. [d] 1a (2 equiv.) was used. [e] Under traditional heating for $4 \mathrm{~h}$ at $80^{\circ} \mathrm{C}$. 


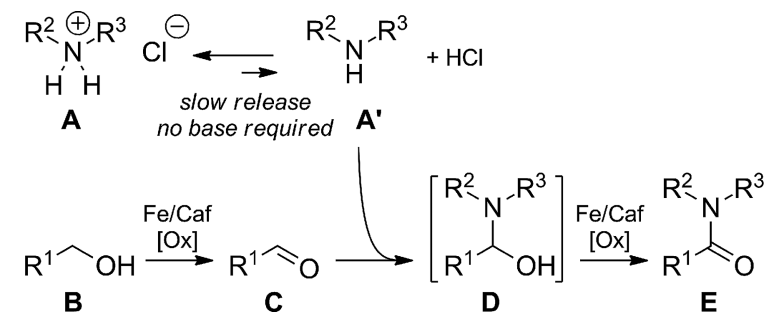

Scheme 1. Proposed mechanism for microwave-promoted amide formation.

An exemplification of this method was then performed by using the iron/caffeine/microwave activation combination (see Scheme 2). Benzamides 3aa, 3ab, 3ac, 3ad, and 3ae, which feature oxidizable benzylic positions, were isolated in $48-81 \%$ yield. Remarkably, the hydroxy group of phenyl glycinol $2 \mathbf{c}$ remained unchanged during the reaction, which proved the selectivity of the conditions towards the benzylic alcohols.

In addition, no epimerization at the stereogenic centers was observed by using the microwave-promoted conditions. Amide 3aa was also obtained in $84 \%$ yield by using $(\alpha)$ methylbenzylamine and concentrated $\mathrm{HCl}$ to preform 2a in situ, which proves that this procedure could be applied to

$$
\text { (2) equiv.) }
$$
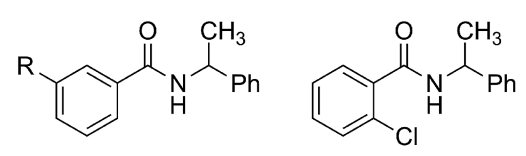

Scheme 2. Scope and limitations for microwave-assisted formation of benzamides. Reagents and conditions: $\mathbf{2 a}-\mathbf{2 k}(0.5 \mathrm{mmol}), \mathbf{1 a}-\mathbf{1 g}$ (1.0 mmol), TBHP $\left(70 \%\right.$ in $\left.\mathrm{H}_{2} \mathrm{O}, 3.0 \mathrm{mmol}\right), \mathrm{FeCl}_{2} \cdot 4 \mathrm{H}_{2} \mathrm{O}$ (0.025 mmol), caffeine $(0.05 \mathrm{mmol}), \mathrm{CH}_{3} \mathrm{CN}(1 \mathrm{~mL}), 130^{\circ} \mathrm{C}, \mathrm{MW}$, 30-45 min. Isolated yields are reported. The TOF (turnover frequency) is reported in $\mathrm{h}^{-1}$ within the brackets (Cy = cyclohexyl). [a] Amine $(0.5 \mathrm{mmol})$ and $\mathrm{HCl}(12 \mathrm{~N}, 0.5 \mathrm{mmol})$ were used. highly hygroscopic and difficult to handle hydrochloride salts. Alkylamines that contained the butyl, cyclohexyl, or tert-butyl group (i.e., $\mathbf{2 f}, \mathbf{2} \mathbf{g}$, and $\mathbf{2 h}$ ) gave the corresponding amides in 71,73 , and $77 \%$ yield, respectively. The beneficial effect of the use of a microwave is highlighted by this last result, as the corresponding yield of $\mathbf{3 a h}$ under traditional conditions was only $59 \% .{ }^{[11 c]}$ Benzoylated morpholine 3ai, dibenzylamine 3aj, and sarcosine methyl ester 3ak were isolated in $64-69 \%$ yield. Finally, the aromatic moiety of hydroxy partner 1 was varied and submitted to a reaction with 2a. A chloro substituent did not have an impact on the reaction (e.g., 3ba, $73 \%$ yield; 3da, $71 \%$ yield), whereas a nitro and methoxy group strongly decreased the yield (e.g., 3ca, 3ea, and 3fa, 52-59\% yield). Finally, 2-chlorobenzyl alcohol $\mathbf{1 g}$, which is more hindered than $\mathbf{1 b}$ and 1d, underwent the reaction to yield amide 3ga in $49 \%$ yield. It is important to stress that the TOF values ${ }^{[19]}$ that were obtained as a result of microwave activation (TOF 14.7$33.6 \mathrm{~h}^{-1}$ ) are significantly higher than those of other reports $\left(\mathrm{TOF}<11 \mathrm{~h}^{-1}\right)$. ${ }^{[11 \mathrm{c}]}$

Finally, we envisioned that this reaction was possible by using directly natural sources of caffeine, coffee beans, or tea leaves. Indeed, it has already been shown that the formation of $\mathrm{Ag}, \mathrm{Pd}$, and $\mathrm{Fe}$ nanoparticles with caffeine/polyphenols is possible by using coffee or tea extract. ${ }^{[20]}$ Thus, Arabica and Robusta coffee beans were evaluated in varying quantities along with water or chloroform as an additive to ensure good extraction of the caffeine (see Table 2, Entries 1-6). However, the yield of 3aa could not exceed $58 \%$. Using crushed beans did not improve the reaction results (see Table 2, Entry 4). Similar results were obtained with tea leaves (see Table 2, Entry 7). As shown previously (see Table 1, Entry 13), the reaction in the absence of caffeine afforded a $66 \%$ yield of 3aa. These data demonstrate that, apart from caffeine, other organic compounds that are contained in the beans might be extracted during the reaction process, and those undesired compounds might react and, hence, consume the reagents or poison the catalyst in the reaction media.

Table 2. Reactions in the presence of coffee beans or tea leaves. ${ }^{[a]}$

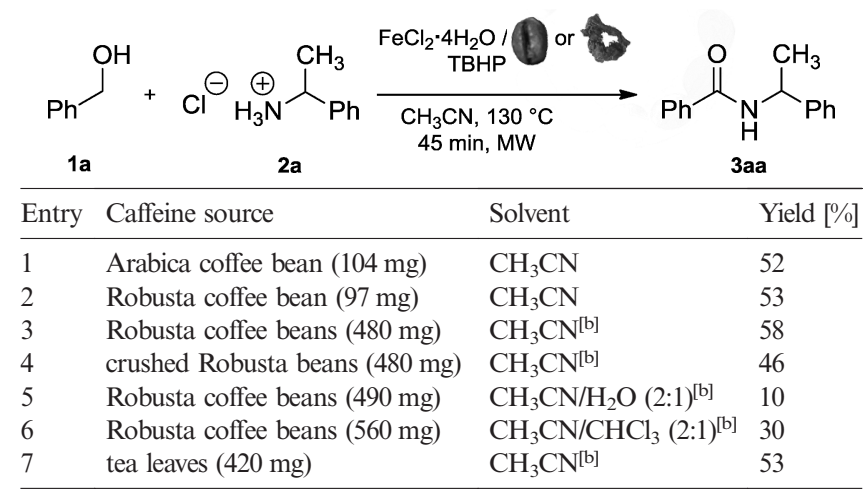

[a] Reagents and conditions: $\mathbf{2 a}(0.5 \mathrm{mmol}), \mathbf{1 a}(1.0 \mathrm{mmol}), \mathrm{TBHP}$ (3.0 mmol), $\mathrm{FeCl}_{2} \cdot 4 \mathrm{H}_{2} \mathrm{O}(0.025 \mathrm{mmol}), \mathrm{CH}_{3} \mathrm{CN}(1 \mathrm{~mL}), 130^{\circ} \mathrm{C}$. [b] The volume of the solvent was $1.5 \mathrm{~mL}$. 


\section{Conclusions}

In summary, we demonstrated that the unique catalytic system that involves iron(II) and caffeine as a stabilizing ligand was compatible with microwave activation to efficiently perform a domino benzamide formation with TOFs up to $33.6 \mathrm{~h}^{-1}$. In only 30 to $45 \mathrm{~min}$, a variety of benzamides were formed directly from alcohols and amine hydrochlorides in yields up to $84 \%$. The importance of microwave irradiation was confirmed when a low yield was obtained by traditional heating. In addition, it was shown that amine hydrochlorides could be formed in situ directly from the corresponding amine and concentrated $\mathrm{HCl}$, thus allowing the use of a wide range of amines, the hydrochloride salts of which would be hygroscopic and difficult to handle.

\section{Experimental Section}

General Methods: All reagents were purchased from chemical suppliers and used without further purification. The ${ }^{1} \mathrm{H}$ and ${ }^{13} \mathrm{C} N M R$ spectroscopic data were recorded with Bruker Avance DPX $200 \mathrm{MHz}$ and Bruker Avance AM $300 \mathrm{MHz}$ spectrometers. The chemical shifts were calibrated by using the solvent signals as internal references $\left(\mathrm{CHCl}_{3}, \delta=7.26 \mathrm{ppm}\right.$ for ${ }^{1} \mathrm{H}$ NMR and $\mathrm{CDCl}_{3}$, $\delta=77.16 \mathrm{ppm}$ for ${ }^{13} \mathrm{C} \mathrm{NMR}$; [D 6 DMSO, $\delta=2.50 \mathrm{ppm}$ for ${ }^{1} \mathrm{H}$ NMR and $\left[\mathrm{D}_{6}\right] \mathrm{DMSO}, \delta=39.52 \mathrm{ppm}$ for $\left.{ }^{13} \mathrm{C} \mathrm{NMR}\right)$. Analytical high performance liquid chromatography was performed on a Waters Millenium 717 that was equipped with an autosampler and had a variable wavelength diode detector. A Chromolith RP18 column $(50 \times 4.6 \mathrm{~mm})$ was employed, and a flow rate of $5 \mathrm{~mL} \mathrm{~min}^{-1}$ was used with a linear gradient of $\mathrm{CH}_{3} \mathrm{CN}$ in water of $0-100 \%$ $(0.1 \%$ TFA) over $4.5 \mathrm{~min}$. Flash chromatography was performed by using prepacked silica columns on a Biotage ${ }^{\circledR}$ IsoleraTM Four system. Reactions were performed in a Biotage ${ }^{\circledR}$ Initiator+ microwave synthesizer. The temperature was measured with an IR sensor on the outer surface of the reaction vial. The general procedures below for the iron-catalyzed synthesis of the amides under microwave activation involve the reaction of $(\alpha)$-methylbenzylamine $\cdot \mathrm{HCl}$ (2a) and benzyl alcohol (1a).

Procedure for Amide Formation by Using a Preformed Amine Hydrochloride: In a microwave reactor $(0.5-2.0 \mathrm{~mL})$ were added $\mathrm{FeCl}_{2} \cdot 4 \mathrm{H}_{2} \mathrm{O} \quad(5.0 \mathrm{mg}, 0.025 \mathrm{mmol}, 5 \mathrm{~mol}-\%)$, caffeine $(9.7 \mathrm{mg}$, $0.05 \mathrm{mmol}, 10 \mathrm{~mol}-\%)$, and $(\alpha)$-methylbenzylamine $\cdot \mathrm{HCl}(78.8 \mathrm{mg}$, $0.5 \mathrm{mmol}$, 1 equiv.). $\mathrm{CH}_{3} \mathrm{CN}(1 \mathrm{~mL})$, benzyl alcohol $(104 \mu \mathrm{L}$, $1.0 \mathrm{mmol}, 2$ equiv.), and tert-butyl hydroperoxide $\left(70 \%\right.$ in $\mathrm{H}_{2} \mathrm{O}$, $140 \mu \mathrm{L}, 2$ equiv.) were then added. After stirring at $130{ }^{\circ} \mathrm{C}$ for 10 min under microwave irradiation, additional tert-butyl hydroperoxide $\left(70 \%\right.$ in $\mathrm{H}_{2} \mathrm{O}, 2$ equiv.) was added, and the mixture was stirred at $130{ }^{\circ} \mathrm{C}$ for $10 \mathrm{~min}$. Once again, tert-butyl hydroperoxide ( $70 \%$ in $\mathrm{H}_{2} \mathrm{O}, 2$ equiv.) was added, and the mixture was stirred at $130{ }^{\circ} \mathrm{C}$ for $10 \mathrm{~min}$. After cooling to room temp., $\mathrm{HCl}(1 \mathrm{~N}$ solution, $5 \mathrm{~mL})$ and AcOEt $(5 \mathrm{~mL})$ were added, and the mixture was extracted with AcOEt $(2 \times 5 \mathrm{~mL})$. The combined organic phases were washed with a saturated aqueous solution of $\mathrm{NaHCO}_{3}(10 \mathrm{~mL})$ and brine $(10 \mathrm{~mL})$, dried with magnesium sulfate, and concentrated under reduced pressure. The crude mixture was purified by chromatography on a silica gel column (cyclohexane/ethyl acetate).

Procedure for Amide Formation by Using an in-situ-Generated Amine Hydrochloride: In a microwave reactor $(0.5-2.0 \mathrm{~mL})$ was added $(\alpha)$-methylbenzylamine $\left(64 \mu \mathrm{L}, 0.5 \mathrm{mmol}, 1\right.$ equiv.). $\mathrm{CH}_{3} \mathrm{CN}$
( $1 \mathrm{~mL})$ and then $\mathrm{HCl}(37 \%$ solution, $42 \mu \mathrm{L}, 0.5 \mathrm{mmol}, 1$ equiv.) were added at $0{ }^{\circ} \mathrm{C}$ until a white precipitate $[(\alpha)$-methylbenzylamine $\cdot \mathrm{HCl}]$ appeared. $\mathrm{FeCl}_{2} \cdot 4 \mathrm{H}_{2} \mathrm{O}(5.0 \mathrm{mg}, 0.025 \mathrm{mmol}, 5 \mathrm{~mol}-\%)$, caffeine $(9.7 \mathrm{mg}, 0.05 \mathrm{mmol}, 10 \mathrm{~mol}-\%)$, benzyl alcohol $(104 \mu \mathrm{L}$, $1.0 \mathrm{mmol}, 2$ equiv.), and tert-butyl hydroperoxide $\left(70 \%\right.$ in $\mathrm{H}_{2} \mathrm{O}$, $140 \mu \mathrm{L}, 2$ equiv.) were then added. After stirring at $130{ }^{\circ} \mathrm{C}$ for 10 min under microwave irradiation, additional tert-butyl hydroperoxide $\left(70 \%\right.$ in $\mathrm{H}_{2} \mathrm{O}, 2$ equiv.) was added, and the mixture was stirred at $130{ }^{\circ} \mathrm{C}$ for $10 \mathrm{~min}$. Once again, tert-butyl hydroperoxide ( $70 \%$ in $\mathrm{H}_{2} \mathrm{O}, 2$ equiv.) was added, and the mixture was stirred at $130{ }^{\circ} \mathrm{C}$ for $10 \mathrm{~min}$. After cooling to room temp., $\mathrm{HCl} 1 \mathrm{~N}$ solution, $5 \mathrm{~mL})$ and AcOEt $(5 \mathrm{~mL})$ were added, and the mixture was extracted with AcOEt $(2 \times 5 \mathrm{~mL})$. The combined organic phases were washed with saturated aqueous $\mathrm{NaHCO}_{3}$ solution $(10 \mathrm{~mL})$ and brine $(10 \mathrm{~mL})$, dried with magnesium sulfate, and concentrated under reduced pressure. The crude mixture was purified by chromatography on a silica gel column (cyclohexane/ethyl acetate).

\section{Characterization of Compounds}

( \pm )- $N$-( $\boldsymbol{\alpha}$-Methylbenzyl)benzamide (3aa): ${ }^{[21]}{ }^{1} \mathrm{H}$ NMR $(200 \mathrm{MHz}$, $\left.\mathrm{CDCl}_{3}\right): \delta=7.90-7.67(\mathrm{~m}, 2 \mathrm{H}), 7.55-7.18(\mathrm{~m}, 8 \mathrm{H}), 6.60(\mathrm{~d}, J=$ $6.9 \mathrm{~Hz}, 1 \mathrm{H}), 5.33(\mathrm{p}, J=7.0 \mathrm{~Hz}, 1 \mathrm{H}), 1.59(\mathrm{~d}, J=6.9 \mathrm{~Hz}, 3$ H) ppm. ${ }^{13} \mathrm{C}$ NMR $\left(75 \mathrm{MHz}, \mathrm{CDCl}_{3}\right): \delta=166.7,143.3,134.6$, $131.4,128.7,128.5,127.3,127.1,126.3,49.2,21.8 \mathrm{ppm}$.

$N$-Benzylbenzamide (3ab): ${ }^{[22]}{ }^{1} \mathrm{H}$ NMR $\left(200 \mathrm{MHz}, \mathrm{CDCl}_{3}\right): \delta=$ 7.89-7.70 (m, $2 \mathrm{H}), 7.57-7.27$ (m, 8 H), 6.67 (s, $1 \mathrm{H}), 4.62$ (d, $J=$ $5.7 \mathrm{~Hz}, 2 \mathrm{H}) \mathrm{ppm} .{ }^{13} \mathrm{C}$ NMR $\left(75 \mathrm{MHz}, \mathrm{CDCl}_{3}\right): \delta=167.5,138.3$, $134.5,131.6,128.9,128.7,128.0,127.7,127.1,44.2 \mathrm{ppm}$.

(S)- $N$-Benzoylphenylglycinol (3ac): ${ }^{[23]}{ }^{1} \mathrm{H}$ NMR $\left(300 \mathrm{MHz},\left[\mathrm{D}_{6}\right]-\right.$ DMSO): $\delta=8.70(\mathrm{~d}, J=8.0 \mathrm{~Hz}, 1 \mathrm{H}), 7.91(\mathrm{~d}, J=6.8 \mathrm{~Hz}, 2 \mathrm{H})$, $7.62-7.43(\mathrm{~m}, 3 \mathrm{H}), 7.40(\mathrm{~d}, J=7.2 \mathrm{~Hz}, 2 \mathrm{H}), 7.32(\mathrm{t}, J=7.4 \mathrm{~Hz}$, $2 \mathrm{H}), 7.23(\mathrm{t}, J=7.1 \mathrm{~Hz}, 1 \mathrm{H}), 5.09(\mathrm{dd}, J=13.6,7.9 \mathrm{~Hz}, 1 \mathrm{H})$, $4.94(\mathrm{~s}, 1 \mathrm{H}), 3.83-3.57(\mathrm{~m}, 2 \mathrm{H}) \mathrm{ppm} .{ }^{13} \mathrm{C} \mathrm{NMR}\left(75 \mathrm{MHz},\left[\mathrm{D}_{6}\right]-\right.$ DMSO): $\delta=166.2,141.4,134.7,131.2,128.2,128.1,127.4,127.0$, $126.8,64.6,56.0 \mathrm{ppm}$.

$(S)-N$-Benzoylphenylalanine (3ad): $:^{[11 \mathrm{c}]} \quad{ }^{1} \mathrm{H} \quad \mathrm{NMR} \quad(200 \mathrm{MHz}$, $\left.\mathrm{CDCl}_{3}\right): \delta=7.72(\mathrm{~d}, J=6.8 \mathrm{~Hz}, 2 \mathrm{H}), 7.63-7.11(\mathrm{~m}, 7 \mathrm{H}), 6.94(\mathrm{~s}$, $1 \mathrm{H}), 6.02(\mathrm{~s}, 1 \mathrm{H}), 5.56(\mathrm{~s}, 1 \mathrm{H}), 4.91(\mathrm{dd}, J=13.9,7.1 \mathrm{~Hz}, 1 \mathrm{H})$, $3.21(\mathrm{qd}, J=13.6,6.8 \mathrm{~Hz}, 2 \mathrm{H}) \mathrm{ppm} .{ }^{13} \mathrm{C} \mathrm{NMR}\left(75 \mathrm{MHz}, \mathrm{CDCl}_{3}\right)$ : $\delta=173.1,167.4,136.7,133.8,132.1,129.5,129.0,128.8,127.4$, 127.2, 54.6, 38.5 ppm.

(S)- $N$-Benzoylphenylalanine tert-Butyl Ester (3ae): ${ }^{[24]}{ }^{1} \mathrm{H} \quad \mathrm{NMR}$ $\left(200 \mathrm{MHz}, \mathrm{CDCl}_{3}\right): \delta=7.70-7.61(\mathrm{~m}, 2 \mathrm{H}), 7.48-7.06(\mathrm{~m}, 8 \mathrm{H})$, $6.60(\mathrm{~d}, J=7.2 \mathrm{~Hz}, 1 \mathrm{H}), 4.88(\mathrm{dt}, J=7.4,5.8 \mathrm{~Hz}, 1 \mathrm{H}), 3.15(\mathrm{~d}$, $J=5.8 \mathrm{~Hz}, 2 \mathrm{H}), 1.35$ (s, $9 \mathrm{H}) \mathrm{ppm} .{ }^{13} \mathrm{C} \mathrm{NMR}\left(75 \mathrm{MHz}, \mathrm{CDCl}_{3}\right)$ : $\delta=170.8,166.8,136.3,134.2,131.7,129.7,128.6,128.5,127.1$, 82.6, 54.0, 38.1, $28.1 \mathrm{ppm}$

$\boldsymbol{N}$-n-Butylbenzamide (3af):[25] ${ }^{1} \mathrm{H}$ NMR $\left(200 \mathrm{MHz}, \mathrm{CDCl}_{3}\right): \delta=$ 7.81-7.68 (m, $2 \mathrm{H}), 7.52-7.29$ (m, 3 H), 6.45 (s, 1 H), 3.51-3.32 (m, $2 \mathrm{H}), 1.68-1.46(\mathrm{~m}, 2 \mathrm{H}), 1.47-1.27(\mathrm{~m}, 2 \mathrm{H}), 0.92(\mathrm{t}, J=7.2 \mathrm{~Hz}$, $3 \mathrm{H}) \mathrm{ppm} .{ }^{13} \mathrm{C}$ NMR $\left(75 \mathrm{MHz}, \mathrm{CDCl}_{3}\right): \delta=167.7,134.9,131.3$, $128.5,127.0,39.9,31.8,20.2,13.8 \mathrm{ppm}$.

$\mathrm{N}$-Cyclohexylbenzamide (3ag): ${ }^{[26]}{ }^{1} \mathrm{H}$ NMR (200 MHz, $\left.\mathrm{CDCl}_{3}\right): \delta$ $=7.87-7.61(\mathrm{~m}, 2 \mathrm{H}), 7.55-7.29(\mathrm{~m}, 3 \mathrm{H}), 6.17(\mathrm{~s}, 1 \mathrm{H}), 4.12-3.78$ $(\mathrm{m}, 1 \mathrm{H}), 2.02-1.74(\mathrm{~m}, 2 \mathrm{H}), 1.68-1.60(\mathrm{~m}, 3 \mathrm{H}), 1.52-1.05(\mathrm{~m}, 5$ H) ppm. ${ }^{13} \mathrm{C} \mathrm{NMR}\left(75 \mathrm{MHz}, \mathrm{CDCl}_{3}\right): \delta=166.8,135.2,131.3$, $128.5,127.0,48.8,33.3,25.6,25.0 \mathrm{ppm}$.

N-tert-Butylbenzamide (3ah):[27] ${ }^{1} \mathrm{H}$ NMR $\left(200 \mathrm{MHz}, \mathrm{CDCl}_{3}\right): \delta=$ 7.87-7.58 (m, $2 \mathrm{H}), 7.58-7.28(\mathrm{~m}, 3 \mathrm{H}), 5.97$ (s, $1 \mathrm{H}), 1.46(\mathrm{~s}, 9$ H) ppm. ${ }^{13} \mathrm{C}$ NMR $\left(75 \mathrm{MHz}, \mathrm{CDCl}_{3}\right): \delta=167.0,136.0,131.1$, 128.5, 126.8, 51.6, $28.9 \mathrm{ppm}$. 
$N$-Benzoylmorpholine (3ai): ${ }^{[28]}{ }^{1} \mathrm{H}$ NMR $\left(200 \mathrm{MHz}, \mathrm{CDCl}_{3}\right): \delta=$ 7.39 (s, $5 \mathrm{H}), 4.18-3.09$ (m, $8 \mathrm{H}) \mathrm{ppm} .{ }^{13} \mathrm{C} \mathrm{NMR}\left(75 \mathrm{MHz}, \mathrm{CDCl}_{3}\right)$ : $\delta=170.5,135.3,129.9,128.6,127.1,66.9 \mathrm{ppm}$.

$\boldsymbol{N}, \boldsymbol{N}$-Dibenzylbenzamide (3aj): ${ }^{[24]}{ }^{1} \mathrm{H}$ NMR (200 MHz, $\left.\mathrm{CDCl}_{3}\right): \delta=$ 7.58-7.44 (m, $2 \mathrm{H}), 7.44-7.28(\mathrm{~m}, 11 \mathrm{H}), 7.17$ (s, $2 \mathrm{H}), 4.71(\mathrm{~s}, 2$ $\mathrm{H}), 4.42$ (s, $2 \mathrm{H}) \mathrm{ppm} .{ }^{13} \mathrm{C} \mathrm{NMR}\left(75 \mathrm{MHz}, \mathrm{CDCl}_{3}\right): \delta=172.3$, $137.0,136.5,136.2,129.7,128.9,128.6,128.5,127.7,127.1,126.8$, 51.6, $46.9 \mathrm{ppm}$.

N-Benzoylsarcosine Methyl Ester (3ak): ${ }^{29]}{ }^{1} \mathrm{H}$ NMR [200 MHz, $\mathrm{CDCl}_{3}$; rotamers, 65:35]: $\delta=7.55-7.29(\mathrm{~m}, 5 \mathrm{H}), 4.25(\mathrm{~s}, 2 \mathrm{H}, 65 \%)$, 3.97 (s, $2 \mathrm{H}, 35 \%$ ), 3.75 (s, $3 \mathrm{H}), 3.08$ (s, $3 \mathrm{H}, 35 \%), 3.01$ (s, $3 \mathrm{H}$, $65 \%$ ) ppm. ${ }^{13} \mathrm{C}$ NMR $\left(75 \mathrm{MHz}, \mathrm{CDCl}_{3}\right): \delta=172.1,169.6,135.5$, $129.9,128.7,128.4,127.2,126.6,53.2,52.4,52.2,49.1,38.7$, $34.4 \mathrm{ppm}$.

( \pm )- $\boldsymbol{N}$-(p-Chlorobenzoyl)- $\alpha$-methylbenzylamine (3ba): ${ }^{[30]}{ }^{1} \mathrm{H}$ NMR $\left(200 \mathrm{MHz}, \mathrm{CDCl}_{3}\right): \delta=7.77-7.58(\mathrm{~m}, 2 \mathrm{H}), 7.45-7.27(\mathrm{~m}, 7 \mathrm{H})$, $6.74(\mathrm{~d}, J=7.4 \mathrm{~Hz}, 1 \mathrm{H}), 5.28(\mathrm{p}, J=7.0 \mathrm{~Hz}, 1 \mathrm{H}), 1.57(\mathrm{~d}, J=$ $6.9 \mathrm{~Hz}, 3 \mathrm{H}) \mathrm{ppm} .{ }^{13} \mathrm{C} \mathrm{NMR}\left(75 \mathrm{MHz}, \mathrm{CDCl}_{3}\right): \delta=165.7,143.1$, 137.7, 133.0, 128.8, 128.8, 128.6, 127.6, 126.3, 49.5, $21.8 \mathrm{ppm}$.

( \pm )- $\boldsymbol{N}$-(p-Nitrobenzoyl)- $\boldsymbol{\alpha}$-methylbenzylamine (3ca): $\mathbf{[}^{[31]}{ }^{1} \mathrm{H} \quad \mathrm{NMR}$ $\left(200 \mathrm{MHz}, \mathrm{CDCl}_{3}\right): \delta=8.27-8.12(\mathrm{~m}, 2 \mathrm{H}), 7.94-7.83(\mathrm{~m}, 2 \mathrm{H})$, $7.41-7.27$ (m, $5 \mathrm{H}), 6.77(\mathrm{~d}, J=7.4 \mathrm{~Hz}, 1 \mathrm{H}), 5.30(\mathrm{p}, J=7.0 \mathrm{~Hz}$, $1 \mathrm{H}), 1.61(\mathrm{~d}, J=6.9 \mathrm{~Hz}, 3 \mathrm{H}) \mathrm{ppm} .{ }^{13} \mathrm{C} \mathrm{NMR}\left(75 \mathrm{MHz}, \mathrm{CDCl}_{3}\right)$ : $\delta=164.8,149.5,142.7,140.2,128.9,128.3,127.8,126.3,123.7$, 49.8, 21.7 ppm.

( \pm )- $\boldsymbol{N}$-( $\boldsymbol{m}$-Chlorobenzoyl)- $\boldsymbol{\alpha}$-methylbenzylamine (3da): ${ }^{[32]}{ }^{1} \mathrm{H}$ NMR $\left(200 \mathrm{MHz}, \mathrm{CDCl}_{3}\right): \delta=7.74(\mathrm{~d}, J=1.6 \mathrm{~Hz}, 1 \mathrm{H}), 7.62(\mathrm{~d}, J=$ $7.6 \mathrm{~Hz}, 1 \mathrm{H}), 7.49-7.17(\mathrm{~m}, 7 \mathrm{H}), 6.72(\mathrm{~s}, 1 \mathrm{H}), 5.29$ (p, $J=7.0 \mathrm{~Hz}$, $1 \mathrm{H}), 1.58(\mathrm{~d}, J=6.9 \mathrm{~Hz}, 3 \mathrm{H}) \mathrm{ppm} .{ }^{13} \mathrm{C} \mathrm{NMR}\left(75 \mathrm{MHz}, \mathrm{CDCl}_{3}\right)$ : $\delta=165.5,143.0,136.5,134.7,131.5,129.9,128.8,127.6,127.4$, $126.3,125.2,49.5,21.7 \mathrm{ppm}$.

( \pm )- $\boldsymbol{N}$-(m-Methoxybenzoyl)- $\boldsymbol{\alpha}$-methylbenzylamine (3ea): $:^{[8]}{ }^{1} \mathrm{H}$ NMR $\left(200 \mathrm{MHz}, \mathrm{CDCl}_{3}\right): \delta=7.50-7.15(\mathrm{~m}, 8 \mathrm{H}), 7.15-6.76(\mathrm{~m}, 1 \mathrm{H})$, $6.57(\mathrm{~d}, J=7.4 \mathrm{~Hz}, 1 \mathrm{H}), 5.31(\mathrm{p}, J=7.0 \mathrm{~Hz}, 1 \mathrm{H}), 3.80(\mathrm{~s}, 3 \mathrm{H})$, $1.59(\mathrm{~d}, J=6.9 \mathrm{~Hz}, 3 \mathrm{H}) \mathrm{ppm} .{ }^{13} \mathrm{C} \mathrm{NMR}\left(75 \mathrm{MHz}, \mathrm{CDCl}_{3}\right): \delta=$ $166.6,159.9,143.3,136.1,129.6,128.8,127.5,126.3,118.8,117.7$, $112.5,55.5,49.4,21.8 \mathrm{ppm}$.

( \pm )- $\boldsymbol{N}$-( $\boldsymbol{m}$-Nitrobenzoyl)- $\alpha$-methylbenzylamine (3fa): ${ }^{[33]}{ }^{1} \mathrm{H} \quad \mathrm{NMR}$ $\left(200 \mathrm{MHz}, \mathrm{CDCl}_{3}\right): \delta=8.57(\mathrm{t}, J=1.9 \mathrm{~Hz}, 1 \mathrm{H}), 8.29$ (ddd, $J=$ $8.2,2.2,1.1 \mathrm{~Hz}, 1 \mathrm{H}), 8.22-8.05(\mathrm{~m}, 1 \mathrm{H}), 7.57(\mathrm{t}, J=8.0 \mathrm{~Hz}, 1$ $\mathrm{H}), 7.43-7.23(\mathrm{~m}, 5 \mathrm{H}), 7.02(\mathrm{~d}, J=7.6 \mathrm{~Hz}, 1 \mathrm{H}), 5.31$ (p, $J=$ $7.0 \mathrm{~Hz}, 1 \mathrm{H}), 1.61(\mathrm{~d}, J=6.9 \mathrm{~Hz}, 3 \mathrm{H}) \mathrm{ppm} .{ }^{13} \mathrm{C} \mathrm{NMR}(75 \mathrm{MHz}$, $\left.\mathrm{CDCl}_{3}\right): \delta=164.4,148.2,142.7,136.2,133.5,129.9,128.9,127.7$, 126.4, 126.1, 121.9, 49.9, $21.7 \mathrm{ppm}$.

( \pm )- $\mathrm{N}$-(o-Chlorobenzoyl)- $\boldsymbol{\alpha}$-methylbenzylamine (3ga):[34] ${ }^{1} \mathrm{H}$ NMR $\left(200 \mathrm{MHz}, \mathrm{CDCl}_{3}\right): \delta=7.76-7.55(\mathrm{~m}, 1 \mathrm{H}), 7.55-7.27(\mathrm{~m}, 8 \mathrm{H})$, $6.51(\mathrm{~d}, J=5.2 \mathrm{~Hz}, 1 \mathrm{H}), 5.34(\mathrm{p}, J=7.0 \mathrm{~Hz}, 1 \mathrm{H}), 1.61(\mathrm{~d}, J=$ $6.9 \mathrm{~Hz}, 3 \mathrm{H}) \mathrm{ppm} .{ }^{13} \mathrm{C} \mathrm{NMR}\left(75 \mathrm{MHz}, \mathrm{CDCl}_{3}\right): \delta=165.7,142.9$, $135.2,131.4,130.7,130.4,130.3,128.8,127.6,127.2,126.4,49.7$, $21.9 \mathrm{ppm}$.

Supporting Information (see footnote on the first page of this article): ${ }^{1} \mathrm{H}$ and ${ }^{13} \mathrm{C}$ NMR spectra of all compounds and chiral HPLC analysis.

\section{Acknowledgments}

This work was realized thanks to the funding from the Centre National de la Recherche Scientifique (CNRS) and the Université Montpellier 2.
[1] J. S. Carey, D. Laffan, C. Thomson, M. T. Williams, Org. Biomol. Chem. 2006, 4, 2337-2347.

[2] E. Valeur, M. Bradley, Chem. Soc. Rev. 2009, 38, 606-631.

[3] a) H. Lundberg, F. Tinnis, N. Selander, H. Adolfsson, Chem. Soc. Rev. 2014, 43, 2714-2742; b) V. R. Pattabiraman, J. W. Bode, Nature 2011, 480, 471-479; c) R. Garcia-Alvarez, P. Crochet, V. Cadierno, Green Chem. 2013, 15, 46-66; d) R. M. Lanigan, T. D. Sheppard, Eur. J. Org. Chem. 2013, 7453-7465.

[4] L. Gu, J. Lim, J. L. Cheong, S. S. Lee, Chem. Commun. 2014, 50, 7017-7019.

[5] C. L. Allen, J. M. J. Williams, Chem. Soc. Rev. 2011, 40, 3405 3415.

[6] a) C. Gunanathan, Y. Ben-David, D. Milstein, Science 2007, 317, 790-792; b) T. Naota, S.-I. Murahashi, Synlett 1991, 693694.

[7] a) T. Zweifel, J. V. Naubron, H. Grutzmacher, Angew. Chem. Int. Ed. 2009, 48, 559-563; Angew. Chem. 2009, 121, 567; b) K.-i. Fujita, Y. Takahashi, M. Owaki, K. Yamamoto, R. Yamaguchi, Org. Lett. 2004, 6, 2785-2788.

[8] X. Bantreil, C. Fleith, J. Martinez, F. Lamaty, Chem CatChem 2012, 4, 1922-1925.

[9] K. Azizi, M. Karimi, F. Nikbakht, A. Heydari, Appl. Catal. A 2014, 482, 336-343.

[10] X.-F. Wu, M. Sharif, A. Pews-Davtyan, P. Langer, K. Ayub, M. Beller, Eur. J. Org. Chem. 2013, 2783-2787.

[11] a) S. C. Ghosh, J. S. Y. Ngiam, A. M. Seayad, D. T. Tuan, C. W. Johannes, A. Chen, Tetrahedron Lett. 2013, 54, 4922-4925; b) S. Gaspa, A. Porcheddu, L. De Luca, Org. Biomol. Chem. 2013, 11, 3803-3807; c) X. Bantreil, N. Kanfar, N. Gehin, E. Golliard, P. Ohlmann, J. Martinez, F. Lamaty, Tetrahedron 2014, 70, 5093-5099.

[12] a) P. Lidström, J. Tierney, B. Wathey, J. Westman, Tetrahedron 2001, 57, 9225-9283; b) C. O. Kappe, A. Stadler, Microwaves in Organic and Medicinal Chemistry, Wiley-VCH, Weinheim, Germany, 2005; c) C. O. Kappe, Angew. Chem. Int. Ed. 2004, 43, 6250-6284; Angew. Chem. 2004, 116, 6408; d) A. de la Hoz, A. Loupy, Microwaves in Organic Synthesis 3rd ed., WileyVCH, Weinheim, Germany, 2012, vol. 1 and 2.

[13] N. Lukasik, E. Wagner-Wysiecka, Curr. Org. Synth. 2014, 11, 592-604.

[14] As in previous reports, the protection of the nitrogen atom as an ammonium salt was necessary for this reaction. Its controlled deprotonation was essential to avoid side reactions between the amine and TBHP, which would lead to a decrease in the yield. Indeed, the direct use of $(\alpha)$-methylbenzylamine, instead of corresponding ammonium salt, did not allow for any conversion into amide 3aa.

[15] E. B. Leffler, H. M. Spencer, A. Burger, J. Am. Chem. Soc. 1951, 73, 2611-2613.

[16] The pKa value of pyridine (5.14) corresponds to the $\mathrm{pKa}$ of the conjugate acid/base pair pyridinium ion/pyridine. In the remainder of the publication, the same analogy could be applied, that is, the $\mathrm{p} K_{\mathrm{a}}$ value of a base corresponds to the $\mathrm{p} K_{\mathrm{a}}$ of the conjugate acid/base pair.

[17] R. Vanjari, T. Guntreddi, K. N. Singh, Org. Lett. 2013, 15, 4908-4911.

[18] a) L. Hallberg, L. Rossander, Human Nutrition: Applied Nutrition 1982, 36, 116-123; b) S. Kolaylı, M. Ocak, M. Küçük, R. Abbasolu, Food Chem. 2004, 84, 383-388.

[19] The turnover frequency is defined as the following: TOF = $(\mathrm{mmol}$ of product $) /[(\mathrm{mmol}$ of catalyst $) \times($ reaction time $)]$.

[20] a) G. E. Hoag, J. B. Collins, J. L. Holcomb, J. R. Hoag, M. N. Nadagouda, R. S. Varma, J. Mater. Chem. 2009, 19, 86718677 ; b) M. N. Nadagouda, R. S. Varma, Green Chem. 2008, 10, 859-862; c) L. Huang, X. Weng, Z. Chen, M. Megharaj, R. Naidu, Spectrochim. Acta Part A 2014, 130, 295-301.

[21] C. K. De, E. G. Klauber, D. Seidel, J. Am. Chem. Soc. 2009, $131,17060-17061$. 
[22] N. Shangguan, S. Katukojvala, R. Greenberg, L. J. Williams, J. Am. Chem. Soc. 2003, 125, 7754-7755.

[23] K.-Y. Lee, Y.-H. Kim, M.-S. Park, C.-Y. Oh, W.-H. Ham, J. Org. Chem. 1999, 64, 9450-9458.

[24] H.-g. Park, M.-J. Kim, M.-K. Park, H.-J. Jung, J. Lee, S.-h. Choi, Y.-J. Lee, B.-S. Jeong, J.-H. Lee, M.-S. Yoo, J.-M. Ku, S.s. Jew, J. Org. Chem. 2005, 70, 1904-1906.

[25] M. Zhang, P. Vedantham, D. L. Flynn, P. R. Hanson, J. Org. Chem. 2004, 69, 8340-8344.

[26] M. Kitamura, T. Suga, S. Chiba, K. Narasaka, Org. Lett. 2004, 6, 4619-4621.

[27] S. C. Ghosh, J. S. Y. Ngiam, A. M. Seayad, D. T. Tuan, C. L. L. Chai, A. Chen, J. Org. Chem. 2012, 77, 8007-8015.

[28] R. Tank, U. Pathak, M. Vimal, S. Bhattacharyya, L. K. Pandey, Green Chem. 2011, 13, 3350-3354.
[29] S. C. Ghosh, J. S. Y. Ngiam, C. L. L. Chai, A. M. Seayad, T. T. Dang, A. Chen, Adv. Synth. Catal. 2012, 354, 1407-1412.

[30] Y. Kasashima, A. Uzawa, K. Hashimoto, Y. Yokoyama, T. Mino, M. Sakamoto, T. Fujita, J. Oleo Sci. 2010, 59, 607-613.

[31] Z. Wang, Y. Zhang, H. Fu, Y. Jiang, Y. Zhao, Org. Lett. 2008, 10, 1863-1866.

[32] T. Yokomatsu, A. Arakawa, S. Shibuya, J. Org. Chem. 1994, 59, 3506-3508.

[33] H. R. Arias, R.-X. Gu, D. Feuerbach, B.-B. Guo, Y. Ye, D.-Q. Wei, Biochemistry 2011, 50, 5263-5278.

[34] Y. Hanzawa, Y. Kasashima, K. Tomono, T. Mino, M. Sakamoto, T. Fujita, J. Oleo Sci. 2012, 61, 393-399. 